\title{
THE COMPETITIVENESS OF THE REPUBLIC OF CROATIA ON THE EUROPEAN UNION TOURISM MARKET
}

\author{
Ana Portolan
}

https://doi.org/10.20867/tosee.05.15

\begin{abstract}
Purpose - The main purpose of this article is to determine competitive position of the Republic of Croatia on the European Union tourism market by analyzing Travel and Tourism Competitiveness Index 2017 (TTCI). Also, this paper aims to compare TTCI of the Republic of Croatia and leading EU countries by international tourism receipts in order to define the weakest point of its competitiveness.

Methodology - To achieve the purpose cluster analysis and multidimensional scaling have been used. By cluster analysis, different clusters have been identified, and distance between clusters according their mutual vicinity has been measured by multidimensional scaling.

Findings - The K-means cluster analysis split the sample into the two distinct clusters. The first cluster consists of 13 countries and the second one of 15 countries. By comparing the TTCI of Republic of Croatia with leading EU countries by international tourism receipts it has been concluded that Republic of Croatia has the worst results in Air Transport Infrastructure, Ground and Port Infrastructure, Cultural Resources and Business Travel, Human Resources and Labor Market, and ICT Readiness.

Contribution -The results point out the main weaknesses of Croatian tourism and also highlight areas where concrete and urgent actions are required in order to reach the best competitive position. The findings of this article are valuable for state authorities as a base for definition and classification of tourism policy goals and for tourism strategy development as well as for general decision making. The results are also beneficial as guideline for increasing tourism revenues. Keywords competitiveness, Republic of Croatia, Travel and Tourism Competitiveness Index
\end{abstract}

\section{INTRODUCTION}

In 1950 top ten tourism destinations realized $88 \%$ of total international tourist arrivals while in 2017 that number decreased to $42 \%$ (UNWTO, 2018). Since the number of tourist arrivals in period between 1950 and 2017 constantly growths that decline is result of destinations' number increasing due to the effects of globalization process. On the increasingly saturated market, the fundamental task of destination management is to understand how tourism destination competitiveness can be enhanced and sustained (Dragičević et al., 2012). The growth of competitiveness among tourism destinations has become a distinguished phenomenon in simultaneity with emergence of new destinations (Blanco-Cerradelo et al., 2018). Main goal of destination management has changed from realizing a higher number of arrivals to achieving destination competitive advantage. The methodology of achieving sustainable competitive advantage of tourism destination 
ToSEE - Tourism in Southern and Eastern Europe, Vol. 5, pp. 581-595, 2019

A. Portolan: THE COMPETITIVENESS OF THE REPUBLIC OF CROATIA ON THE ...

became a crucial element. As competing among tourism destinations raises, especially in last two decades, the necessity to increase awareness of destination competitiveness' capability appeared, as well as a need to discuss the strengths and weaknesses of direct and indirect competitors (Pulido-Fernandez \& Rodiguez-Diaz, 2016).

At today's increasingly open and integrated tourism market, competitiveness takes central position of all countries involved in tourism development. Competitiveness, strategies for achieving competitive advantage and measuring tourism destination competitiveness are the most commonly used syntagm. The key of its popularity is the availability of all components of tourist product on the tourism market and hard differentiation in competing with main and other competitors. For a long time, tourism business entities, both legal and physical, struggled with the competitiveness' reestablishment because of a desire for rapid prosperity and expansion in the short term. Today, the tourism offer, on one hand, is struggling with the high level of competitiveness and rapidly changing demand from the market. On other hand, tourism products' life cycle became shorter due to the rapid technological changes and the moral obligation to meet tourism demand that becomes more and more sophisticated. In order to return to the competition for a better position on a tourism market (to become a competitive), tourism offer has to come closer to the demand by listening tourists' needs and promptly responding on them, while to respect competitors and to take a full benefit of advantages and opportunities at the same time. Global competitiveness has forced all business subjects, regardless their size and business volume, to reorganise and restructure, not only to compete but to survive on the tourism market.

The tourism destination success is determined by its proportionate competitiveness on the international tourism market (Bošković, Težak Damijanić \& Saftić, 2010). The concept of tourism destination competitiveness is the theme of intensified researches by scientists, practitioners and politicians as a result of economic tourism potential increasing and out of rules competition between business entities in tourism as well as between tourism destinations, with the aim of attracting tourists whose number increases year after year. The importance of destination competitiveness in tourism has been recognized as a scientific level and three eminent journals have issued special editions closely related to the competitiveness (Tourism 1999; Tourism Management 2000; Tourism Economics, 2005).

In 2017 the number of international tourist arrivals reached record level of 1,326 million, $7 \%$ more than in 2016, what means that almost sixth of the world's total population is travelling. In the same year, the international tourism receipt has reached US\$1,340 billion of which $39 \%$ (US\$ 519 billion) has been realized in Europe (UNWTO, 2018). In 2017 in Republic of Croatia were 17, 4 million tourists what is increase of almost 12\% comparing to the previous year. In the same year, total receipt from foreign tourists was US\$ 8, 4 billion comparing to US\$ 7, 64 billion in 2016. The share of tourism in GDP in 2017 in Republic of Croatia was at high level of 19,6\% (Ministry of tourism of Republic of Croatia, 2018). According Andrades and Dimanche (2017), Republic of Croatia is country with less-developed economies because it is increasingly focusing on tourism as a path for growth, development, and foreign exchange earnings. 
ToSEE - Tourism in Southern and Eastern Europe, Vol. 5, pp. 581-595, 2019

A. Portolan: THE COMPETITIVENESS OF THE REPUBLIC OF CROATIA ON THE

The previously mentioned statistical data point out the importance of tourism on a global and national level, resulting with an "out of rules" competition between tourism destinations for as many tourists as possible. In parallel with tourist arrivals and revenues growth, competitiveness among tourism destinations raises. The methods and strategies that tourism destinations use to compete indicate the necessity for more detailed destination competitiveness analysis, especially the factors that determine it.

In this paper, based on 14 indicators, competitiveness of Republic of Croatia and EU countries will be analyzed. Clustering of those countries according their scores in 14 indicators and their competitive position on the map will be examined. Also, this paper aims to compare Travel and Tourism Competitiveness Index (hereafter TTCI) of the Republic of Croatia to the leading EU countries by international tourism receipts in order to determine the weakest point of its competitiveness; to fill the lack of literature dealing with individually tourism destination's competitiveness of Republic of Croatia and in parallel with other EU members, and to define strategies for future action in order to overcome the weaknesses of current tourism policy.

In order to achieve the main goals of this paper secondary data of TTCI, developed by World Economic Forum, have been employed. TTCI was use because it remains a valuable tool to measure "the performance of a destination compared to competitors" (Croes \& Kubickova, 2013:146), it is useful for examining destination competitiveness at the country level, and it is longitudinal research that uses and measures the same variables. Methodologies that have been used are cluster analysis and multidimensional scaling (Kayar \& Kozak, 2010).

\section{THEORETICAL FRAMEWORK}

In this section different approaches towards destination competitiveness research and its measurement have been discussed.

\subsection{Conceptualisation of Destination Competitiveness}

Competitiveness is a broad, multidimensional and complex concept which has led to the multiple definitions and models' analysis (Pulido-Fernandez \& Rodriguez-Diaz, 2016). World Economic Forum has defined it as capability to create, produce, and market goods and/or services whose price and non-price quality form more attractive set of benefits than those offered by other business entities (World Competitiveness Reports in Kunst 2009). According to the United Nation Organisation for Economic Co-operation and development competitiveness of country/industry and/or sector is level to which it is able to produce goods and services under the free and fair market conditions by passing international market's test, preserving and increasing real income of local community/employees (in National Competitiveness Council, 2019).

In the last three decades, scientists in tourism, tourism destination managers and international organisation try to contribute in measuring tourism competitiveness of cities, regions and countries, as well as in identifying factors that could be crucially important for better destination competitiveness' position (Abreu Novais, Ruhanen \& 
ToSEE - Tourism in Southern and Eastern Europe, Vol. 5, pp. 581-595, 2019

A. Portolan: THE COMPETITIVENESS OF THE REPUBLIC OF CROATIA ON THE

Arcodia, 2018). De Keyser and Vanhove are the pioneers in tourism destination competitiveness research. In 1994 they first connected competitiveness and tourism destination by defining destination competitiveness as its ability to realize long-term goals more effectively than the international or regional average. Their view is that destination if wants to be competitive should be capable to operate more profitable than the average, with lower social costs and without any negative impact on the environment and available resources (De Keyser \& Vanhove, 1994). According to Hassan (2000:239) „destination competitiveness is destination's ability to create and integrate value-added products that sustain its resources while maintaining market position relative to competitors". The most acceptable and citable destination competitiveness definition was developed by Ritchie and Crouch in 2003. They have defined it as ability to increase tourism expenditure, to attract a higher number of visitors by providing them satisfying and memorable experiences in a profitable way while enhancing the well-being of local residents and preserving natural sources for future generations (Ritchie \& Crouch, 2003). From their definition, it arises that tourism competitiveness integrates several dimensions, namely economic, socio-cultural, ecological (sustainable) and political. They have also emphasised that tourism destination competitiveness is a function of two components, comparative advantage based on core resources and key attractors, and competitive advantage based on capability to manage those resources and attractors (Crouch \& Ritchie 2004). According to Dwyer and Kim (2003) destination competitiveness is "ability of a destination to deliver goods and services that perform better than other destinations on those aspects of the tourism experience considering being important by tourists" (Dwyer \& Kim, 2003:375) A newer definition of tourism destination competitiveness is the one by Dupeyrad and MacCallum (2013) who have defined it as the ability of the place to optimise its attractiveness for residents and nonresidents, to deliver quality, innovative, and attractive (e.g. providing good value for money) tourism services to the consumers and to gain market shares on the domestic and global market places, while ensuring that the available resources supporting tourism are used efficiently and in a sustainable way.

\subsection{Measuring destination competitiveness}

A lot of scientists have analysed factors that have determined destination competitiveness. Due to those analyses numbers of conceptual models have been developed (De Keyser \& Vanhove, 1994; Ritchie \& Crouch, 1995; Heath, 2002; Dweyer \& Kim, 2003). According Petrović, Miličević and Djeri (2016) those models are not suitable for accurate and quick determination of the achieved level of tourism destination competitiveness. In contrast to conceptual models, Gooroochurn and Sugiyarto have in 2005 established model for measuring and comparing tourism competitiveness on national level that has been empirically applicable. As a basis for developing that model, part of the Competitiveness Monitor (CM) database, has been used. Tourism Competitiveness Monitor is a result of joint work of World Travel and Tourism Council (WTTC) and the Christel DeHann Institute for travel and tourism research at the University of Nottingham. By then, conceptual models of destination competitiveness were based only on the analysis of factors with a lack of specific indicators, while this model was based on concrete indicators that could be collected from various credible publications and had more empirical character. This model was applied only in a relatively short time period from 2005 to 2007 (Craigwell, 2007; Gursoy, Baloglu \& Chi, 
ToSEE - Tourism in Southern and Eastern Europe, Vol. 5, pp. 581-595, 2019

A. Portolan: THE COMPETITIVENESS OF THE REPUBLIC OF CROATIA ON THE

2009) because the World Economic Forum (WEF) developed the TTCI with four subindexes based on 14 key competitiveness elements. The approach of the World Economic Forum to tourism competitiveness is similar to the approach of Gooroochurn and Sugiyarto, with the exception of an index based on eight rather than four criteriafactors. The application of this model to the tourism competitiveness analysis has intensified in the last ten years. The reason for its intensification was the awareness of destination managers and tourism policy creators of necessity to create quality basis for decision making on macro, regional and micro level. This model was used by Chin-Tsai and Ya-Ling in analysis of Asian countries destination competitiveness; by Kayar and Kozak in comparing competitiveness of Turkey with European Union members; by Bălan, Balaure and Vegheş in analysis of competitiveness of 25 top tourism destinations; by Ivanov and Webster in analysing relationship between destination competitiveness and globalisation; by Dragoş Cîrstea in achieving a comparison of the tourism competitiveness between the first 15 most economically competitive countries according to the Global Competitiveness Report (Chin-Tsai \& Ya-Ling, 2009; Bălan, Balaure \& Vegheş, 2009; Kayar \& Kozak, 2010; Ivanov \& Webster, 2013; Dragoş Cîrstea, 2014). Chin-Tsai and Ya-Ling have, by using grey relation analysis (GRA) and sensitivity analysis, determined weight of different indices from scientific point of view and evaluated tourism competitiveness of Asian countries. (Chin-Tsai \& Ya-Ling, 2009). In the same year Bălan, Balaure and Vegheş have used Pearson's correlation coefficient to research the role of specific factors in destination competitiveness of 25 top tourism destinations according the number of arrivals and tourism receipts. Kayar and Kozak have, by researching the members of European Union and using cluster analysis and multidimensional scaling, determined the existence of three clusters, defined the factors of the crucial importance for competitiveness of those members and enhanced that Turkey is still perceived as country of lower prices (Kayar \& Kozak, 2010).

World Economic Forum monitors tourism competitiveness of 140 countries on an annual basis. The results of monitoring are published in The Travel \& Tourism Competitiveness Report in the form of TTCI that, till 2015, consisted of three sub-indices (T\&T regulatory framework, business environment and infrastructure, and T\&T human, cultural and natural resources), and since 2015 of four sub-indices (enabling environment, T\&T policy and enabling conditions, infrastructure, and natural and cultural resources). Each sub-index includes a range of fourteen indicators, consisting of quantitative and qualitative indicators. Structural elements of those indicators are "hard" econometric data and "soft" data in a form of attitudes of leading experts in tourism. The main indicators, pillars of competitiveness, grouped into four sub-indices are business environment, safety and security, health and hygiene, human resources and labour market, ICT readiness, prioritization of travel and tourism, international openness, price competitiveness, environmental sustainability, air transport infrastructure, ground and port infrastructure, tourist service infrastructure, natural resources, and cultural resources and business travel. The special feature of this model is that the valuation of each of the fourteen indicators is based not only on quantitative indicators derived and based on the data from published sources (UNESCO, UNWTO, WTTC, IATA etc.) but also on the number of qualitative indicators derived from surveys of main stakeholders in tourism of each country covered by the research. (Kunst, 2009). 
ToSEE - Tourism in Southern and Eastern Europe, Vol. 5, pp. 581-595, 2019

A. Portolan: THE COMPETITIVENESS OF THE REPUBLIC OF CROATIA ON THE ...

\section{METHODOLOGY}

This paper analyzed secondary data published by World Economic Forum in "The Travel and Tourism Competitiveness Report", by using the same methodology (cluster analysis and multidimensional scaling) as Kayar and Kozak (2010) used in their research of destination competitiveness of Turkey and EU countries. The reason for using basically identical methods is the fact that cluster analysis identifies clusters, and multidimensional scaling, based on the proximity of elements, measures their distance. The collected data were analysed in two phases. In the first phase, based on 14 factors and using cluster analysis, the surveyed countries were segmented into certain number of clusters. The main mission of the cluster analysis is to sort the raw data by grouping them into clusters that are homogeneous within themselves, while its aim is to find the optimal grouping in which the perceptions within each cluster are similar, but different clusters are dissimilar to one another. In the second phase, non-attributive and nonmetric multidimensional scaling was used to determine the factors of most and least importance in defining the competitiveness of the selected countries. Non-attributive approach used in this research is based on data about objects' similarities (Rajh \&Piri Rajh, 2001).

Table 1: The position of the Republic of Croatia based on TTCI before entering the European Union

\begin{tabular}{|l|c|c|c|c|c|}
\hline \multicolumn{1}{|c|}{ Year } & 2007 & 2008 & 2009 & 2011 & 2013 \\
\hline \multicolumn{1}{|c|}{ Index/Position } & $\mathbf{3 8 / 1 2 4}$ & $\mathbf{3 4 / 1 3 0}$ & $\mathbf{3 4 / 1 3 3}$ & $\mathbf{3 4 / 1 3 9}$ & $\mathbf{3 5} / \mathbf{1 4 0}$ \\
\hline \hline T\&T regulatory framework & $\mathbf{5 8}$ & $\mathbf{3 9}$ & $\mathbf{4 3}$ & $\mathbf{4 2}$ & $\mathbf{4 2}$ \\
Policy rules and regulations & 72 & 66 & 80 & 77 & 96 \\
Environmental sustainability & 52 & 41 & 39 & 46 & 44 \\
Safety and security & 63 & 41 & 42 & 33 & 38 \\
Health and hygiene & 66 & 28 & 33 & 32 & 31 \\
Prioritization of travel and tourism & 57 & 51 & 64 & 72 & 61 \\
\hline Business environment and & & & & & \\
infrastructure & $\mathbf{4 0}$ & $\mathbf{3 8}$ & $\mathbf{3 7}$ & $\mathbf{3 6}$ & $\mathbf{3 9}$ \\
Air transport infrastructure & 80 & 66 & 69 & 66 & 68 \\
Ground transport infrastructure & 46 & 54 & 54 & 54 & 53 \\
Tourism infrastructure & 11 & 10 & 6 & 4 & 5 \\
ICT infrastructure & 34 & 37 & 38 & 35 & 30 \\
Price competitiveness in the T\&T industry & 96 & 98 & 103 & 101 & 109 \\
\hline T\&T human, cultural, and natural & & & & & \\
resources & $\mathbf{1 1}$ & $\mathbf{3 2}$ & $\mathbf{4 3}$ & $\mathbf{4 3}$ & $\mathbf{4 2}$ \\
Human resources & 54 & 50 & 53 & 83 & 93 \\
$\quad$ Education and training & 56 & 53 & 58 & 73 & 83 \\
Availability of qualified labour & 71 & 52 & 60 & 91 & 98 \\
Affinity for Travel \& Tourism & - & 7 & 9 & 20 & 29 \\
Natural sources & 4 & 68 & 69 & 75 & 56 \\
Cultural resources & 36 & 37 & 41 & 31 & 32 \\
\hline
\end{tabular}

Source: Travel \& Tourism Competitiveness Report 2007, 2008, 2009, 2011 and 2013 
ToSEE - Tourism in Southern and Eastern Europe, Vol. 5, pp. 581-595, 2019

A. Portolan: THE COMPETITIVENESS OF THE REPUBLIC OF CROATIA ON THE

In $2013^{1}$ the Republic of Croatia had the highest score in Tourism infrastructure and in Affinity for travel and tourism. After entering the European Union competitive position of Croatia has improved (Croatia jumped from $35^{\text {th }}$ place in 2013 to $33^{\text {rd }}$ place in 2015 and $32^{\text {nd }}$ place in 2017). The Republic of Croatia has become much better in Safety and security, Health and hygiene, Environmental sustainability, Air infrastructure, and Natural resources, but at the same time it has significantly regressed in Business environment (former Policy rules and regulations), ICT readiness, and Prioritization of travel and tourism (Tables 1 and 2).

Table 2: The position of the Republic of Croatia based on TTCI after entering the European Union

\begin{tabular}{|l|c|c|}
\hline \multicolumn{1}{|c|}{ Year } & 2015 & 2017 \\
\hline \multicolumn{1}{|c|}{ Index/Position } & $\mathbf{3 3 / 1 4 1}$ & $\mathbf{3 2 / 1 3 6}$ \\
\hline \hline Enabling environment & $\mathbf{5 2}$ & \\
Business environment & 125 & 114 \\
Safety and security & 28 & 24 \\
Health and hygiene & 18 & 19 \\
Human resources and labour market & 80 & 85 \\
ICT readiness & 38 & 47 \\
\hline T\&T policy and enabling conditions & $\mathbf{3 9}$ & \\
Prioritization of travel and tourism & 74 & 77 \\
International openness & 19 & 26 \\
Price competitiveness & 101 & 100 \\
Environmental sustainability & 42 & 21 \\
\hline Infrastructure & $\mathbf{3 8}$ & \\
Air infrastructure & 53 & 52 \\
Ground and port infrastructure & 44 & 46 \\
Tourist service infrastructure & 6 & 5 \\
\hline Natural and cultural resources & $\mathbf{3 0}$ & \\
Natural resources & 33 & 20 \\
Cultural resources and business travel & 36 & 39 \\
\hline
\end{tabular}

Source: Travel \& Tourism Competitiveness Report 2015 and 2017

A total of $28 \mathrm{EU}$ countries were clustered according to their competitiveness scores on the basis of fourteen factors. Those factors are as follows: Business environment, Safety and security, Health and hygiene, Human resources and labour market, ICT readiness, Prioritization of travel and tourism, International openness, Price competitiveness, Environmental sustainability, Air transport infrastructure, Ground and port infrastructure, Tourist service infrastructure, Natural resources, and Cultural resources and business travel. Data were analyzed using the SPSS 20, 0 program.

In order to determine the weakest point of Croatian competitiveness, comparison of TTCI between Republic of Croatia and leading EU countries by international tourism receipts was completed.

${ }^{1}$ The Republic of Croatia joined the European Union as its $28^{\text {th }}$ member state on July the $1^{\text {st }} 2013$. 
ToSEE - Tourism in Southern and Eastern Europe, Vol. 5, pp. 581-595, 2019

A. Portolan: THE COMPETITIVENESS OF THE REPUBLIC OF CROATIA ON THE ...

\section{RESULTS AND DISCUSSION}

According to the dendrogram from a hierarchical cluster analysis suggesting a twocluster solution, the K-means cluster analysis split the sample (28 EU countries) into the two distinct clusters, compared to three in Kayer and Kozak (2010) research. The Cluster 2 consists of 13 countries (Austria, Belgium, Denmark, Finland, France, Germany, Ireland, Italy, Netherlands, Portugal, Spain, Sweden and United Kingdom) and the Cluster 1 of 15 countries (Bulgaria, Republic of Croatia, Cyprus, Czech Republic, Estonia, Greece, Hungary, Latvia, Lithuania, Luxembourg, Malta, Poland, Romania, Slovak Republic and Slovenia). Countries in the same clusters form a competitor set. To determine the characteristics of each cluster, mean scores of the clusters were computed. Table 3 shows the mean scores of each segment cluster.

Table 3: Factors' mean scores

\begin{tabular}{|l|c|c|}
\hline \multicolumn{1}{|c|}{ Factors of competitiveness } & Cluster 1 & Cluster 2 \\
\hline Business Environment & 4,53 & $\mathbf{5 , 0 5}$ \\
Human Resources and Labour Market & 4,85 & $\mathbf{5 , 4 0}$ \\
ICT Readiness & 5,27 & $\mathbf{5 , 8 1}$ \\
International Openness & 3,99 & $\mathbf{4 , 2 2}$ \\
Price Competitiveness & $\mathbf{4 , 8 5}$ & 4,05 \\
Air Transport Infrastructure & 2,93 & $\mathbf{4 , 5 1}$ \\
Ground and Port Infrastructure & 4,19 & $\mathbf{5 , 1 2}$ \\
Tourist Service Infrastructure & 5,08 & $\mathbf{5 , 5 3}$ \\
Natural Resources & 3,09 & $\mathbf{3 , 8 0}$ \\
Cultural Resources and Business Travel & 2,02 & $\mathbf{4 , 4 4}$ \\
Safety and Security & 5,84 & $\mathbf{5 , 9 6}$ \\
Health and Hygiene & $\mathbf{6 , 3 8}$ & $\mathbf{6 , 3 2}$ \\
Prioritization of Travel and Tourism & 4,75 & $\mathbf{5 , 0 8}$ \\
Environmental Sustainability & 4,44 & $\mathbf{4 , 8 4}$ \\
\hline
\end{tabular}

In the Cluster 1 the means of two factors, covering Price competitiveness and Health and hygiene, were higher comparing to their means in the Cluster 2, and therefore were identified as successful competitiveness factors for the Cluster 1. The Cluster 2 was more successful than the Cluster 1 in all other factors.

Multidimensional scaling analysis was used in order to evaluate the competitive position of EU countries. In multidimensional scaling stress measure (Stress-I or Kruskall stress measure), as the most common measure for evaluating how well or poor a particular configuration reproduces the observed distance matrix, was calculated the first. Its value should be as low as possible (minimization process) because low value indicates a better adjustment between original proximity of the elements and conducted distances. If the Kruskall stress measure (Stress-I) is below 0, 10 it is considered that adjustment is excellent, values above 0,15 are unacceptable, while values between 0,10 and 0,15 are tolerable. For that reason, it can be concluded that findings of this multidimensional scaling analysis represented the data used in this research. 
ToSEE - Tourism in Southern and Eastern Europe, Vol. 5, pp. 581-595, 2019 A. Portolan: THE COMPETITIVENESS OF THE REPUBLIC OF CROATIA ON THE ...

Table 4: Stress and fit measures

\begin{tabular}{|l|r|}
\hline Normalized Raw Stress &, 01381 \\
Stress-I &, 11751 \\
Stress-II &, 24983 \\
S-Stress &, 01637 \\
Dispersion Accounted For (D.A.F.) &, 98619 \\
Tucker's Coefficient of Congruence &, 99307 \\
\hline
\end{tabular}

Dispersion Accounted For (D.A.F.) and Tucker's coefficient of congruence have been calculated besides the Stress-I. Their values are above 0, 90, what indicates that the relative good adjustment between original proximity of the countries and conducted distances has been achieved.

In order to illustrate the competitiveness position of EU countries, previous clustered into two segments, multidimensional scaling was further used.

Final Coordinates (Table 5) and Common space diagram (Figure 1) were employed in order to make a one-by-one comparison between countries. Table 5 displays the coordinates of 28 countries for two dimensions.

\section{Table 5: Final coordinates of countries}

\begin{tabular}{|l|c|c|}
\hline & Dimension 1 & Dimension 2 \\
\hline Austria &, 343 &, 039 \\
Belgium &, 303 &,- 323 \\
Bulgaria &,- 509 &, 553 \\
Croatia &,- 062 &, 569 \\
Cyprus &,- 330 &, 423 \\
Czech Republic &,- 308 &,- 140 \\
Denmark &,- 072 &,- 516 \\
Estonia &,- 452 &,- 338 \\
Finland &,- 179 &,- 461 \\
France & 1,124 &, 069 \\
Germany &, 990 &,- 112 \\
Greece &, 094 &, 440 \\
Hungary &,- 406 &, 041 \\
Ireland &, 109 &,- 152 \\
Italy &, 956 &, 376 \\
Latvia &,- 622 &,- 131 \\
Lithuania &,- 737 &,- 179 \\
Luxembourg &,- 236 &,- 583 \\
Malta &,- 182 &, 234 \\
Netherlands &, 256 &,- 639 \\
Poland &,- 533 &, 192 \\
Portugal &, 280 &, 338 \\
Romania &,- 755 &, 388 \\
Slovak Republic &,- 818 &, 088 \\
Slovenia &,- 515 &, 052 \\
Spain & 1,098 &, 518 \\
Sweden &, 101 &,- 383 \\
United Kingdom & 1,064 &,- 362 \\
\hline
\end{tabular}


ToSEE - Tourism in Southern and Eastern Europe, Vol. 5, pp. 581-595, 2019 A. Portolan: THE COMPETITIVENESS OF THE REPUBLIC OF CROATIA ON THE

The results of multidimensional scaling indicated that in the first dimension France $(1,124)$ and Slovak Republic $(-, 818)$ are countries further from each other. In the second dimension Republic of Croatia $(, 569)$ and Netherlands $(-, 639)$ are countries furthest from each other.

Figure 1: Common space diagram of EU countries

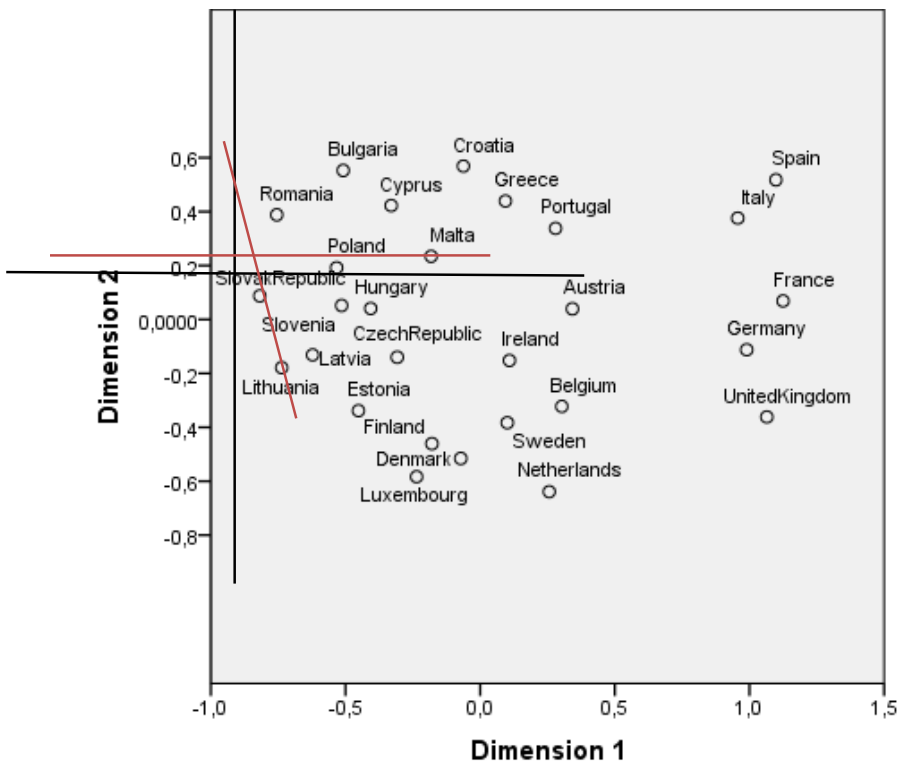

In the second step effectiveness of the factors, used to determine the countries' competitiveness, was analysed also by multidimensional scaling. Before the analysis, Stress-I measure was calculated at the level of 0,11482. Shepard diagram (Figure 2) pointed out that linear fit is available between distances of factors and transformed proximities. 
ToSEE - Tourism in Southern and Eastern Europe, Vol. 5, pp. 581-595, 2019 A. Portolan: THE COMPETITIVENESS OF THE REPUBLIC OF CROATIA ON THE ...

Figure 2: Shepard diagram of distances and disparities between factors

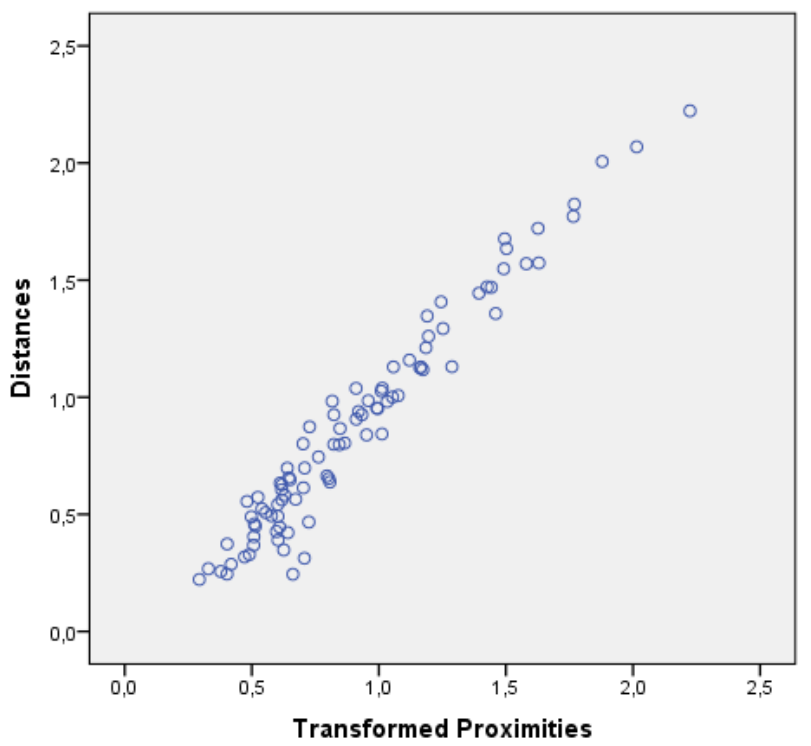

Figure 3: Common space diagram of competitiveness factors

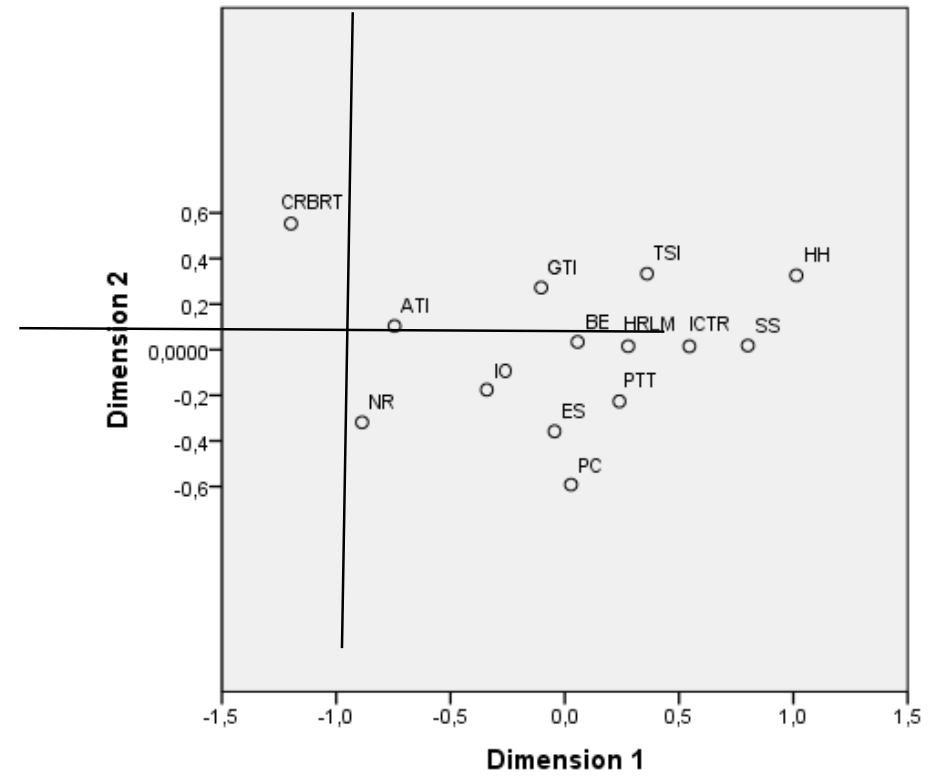

Note. NR - Natural resources; IO - International openness; ES - Environmental sustainability; CRBRT Cultural Resources and Business Travel; ATI - Air transport infrastructure; GTI - Ground and port infrastructure; PTT - Prioritization of travel and tourism; PC - Price competitiveness; BE - Business environment; TSI - Tourist service infrastructure; HRLM - Human resources and labour market; ICTR - ICT readiness; SS - Safety and security; $\mathrm{HH}$ - Health and hygiene 
ToSEE - Tourism in Southern and Eastern Europe, Vol. 5, pp. 581-595, 2019

A. Portolan: THE COMPETITIVENESS OF THE REPUBLIC OF CROATIA ON THE ...

Figure 3 shows the positions of 14 competitiveness factors that have been used to determine the competitive position of countries in two-dimensional map. From the position of competitiveness factors Business environment, Tourist service infrastructure, Human resources and labour market, ICT readiness, Safety and security, and Health and hygiene have similar effects in determining destination competitiveness. The countries grouped in the Cluster 1 are leading in almost all of those factors, except in Health and hygiene. Natural resources, International openness, Environmental sustainability and Price competitiveness have similar impact on competitiveness, but lower compared to all other factors. Additionally, Cultural resources and business travel, Air transport infrastructure and Ground and port infrastructure are effective to a similar degree.

The findings of multidimensional scaling analysis rated Business environment, Tourist service infrastructure, Human resources and labour market, ICT readiness, Safety and security, and Health and hygiene as the factors of competitiveness which make effective distinctions between the sample countries. Compared to Kayer and Kozak (2010) research, only Health and hygiene is detected as common factor that makes effective distinctions between the sample countries.

Comparing the TTCI of Republic of Croatia and leading EU countries by international tourism receipts it is indicated that Republic of Croatia has bad scores (in order from the worst to the less worse) in Cultural resources and business travel, Air transport infrastructure, Ground and port infrastructure, Human resources and labour market, and ICT readiness. This comparison has detected the main weaknesses of Croatian competitiveness compering to Spain, France, Italy and Germany as leading EU countries by international tourism receipts.

\section{Figure 4: Comparative analysis of TTCI of Republic of Croatia and leading EU} countries by international tourism receipts

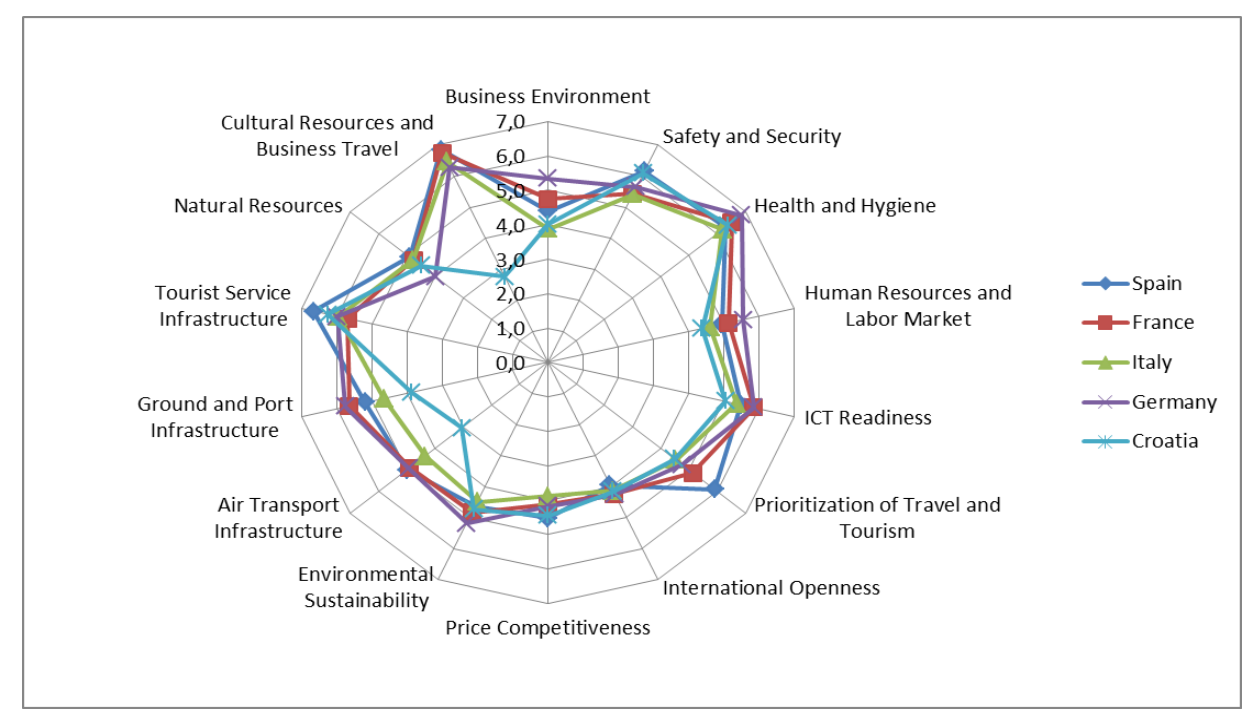


ToSEE - Tourism in Southern and Eastern Europe, Vol. 5, pp. 581-595, 2019

A. Portolan: THE COMPETITIVENESS OF THE REPUBLIC OF CROATIA ON THE

By using only the most important factors of destination competitiveness in comparison of Republic of Croatia with leading EU countries by international receipts it can be concluded that Croatia has the worst scores only in ICT Readiness, and Human resources and labour market.

Figure 5: Comparative analysis of most important factors of destination competitiveness between Republic of Croatia and leading EU countries by international tourism receipts

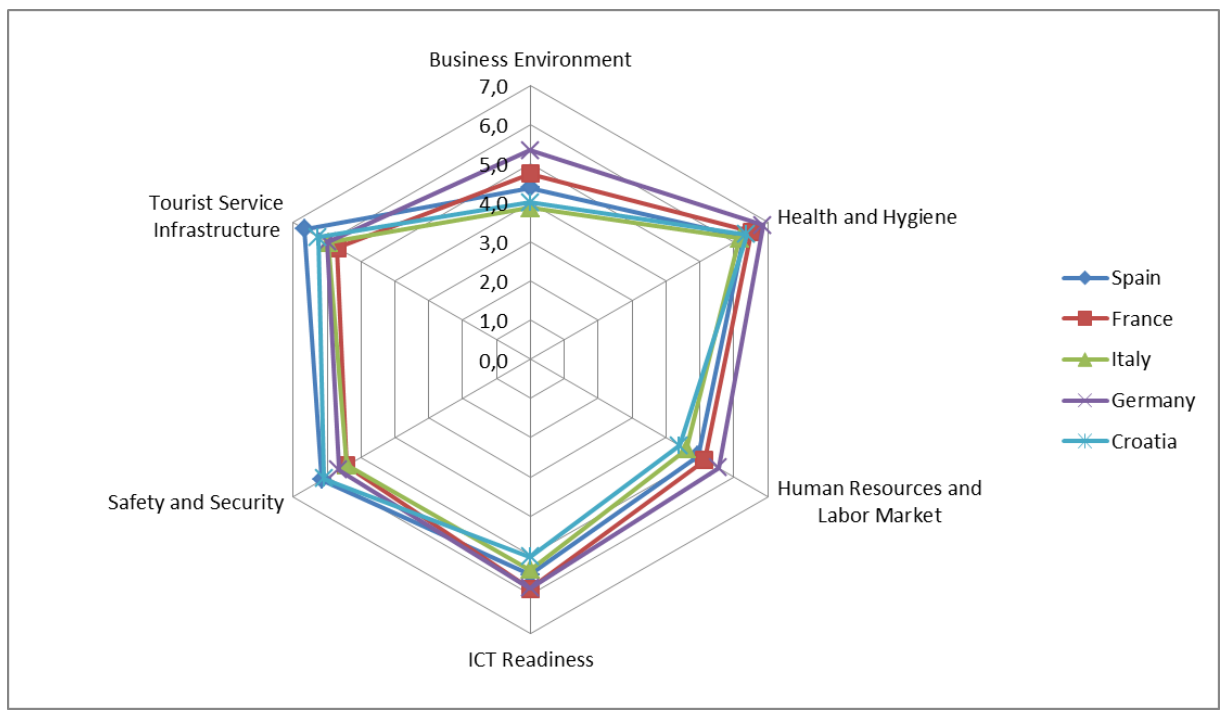

\section{CONCLUSION}

The results of this study indicate the existence of two clusters. The countries grouped in the Cluster 2 (Austria, Belgium, Denmark, Finland, France, Germany, Ireland, Italy, Netherlands, Portugal, Spain, Sweden and United Kingdom) have the best scores of almost all most effective factors of competitiveness (except Health and hygiene), which are Business environment, Tourist service infrastructure, Human resources and labour market, ICT readiness, Safety and security, and Health and hygiene. Countries clustered in the second group (Cluster 1), Bulgaria, Republic of Croatia, Cyprus, Czech Republic, Estonia, Greece, Hungary, Latvia, Lithuania, Luxembourg, Malta, Poland, Romania, Slovak Republic and Slovenia, have the best scores only in Health and hygiene which is also one of the most effective factors of destination competitiveness, and in the Price competitiveness that is less effective factor

This paper reveals several important issues which require Croatian tourism policy maker's attention and that should be addressed and managed if they want to improve the competitive position of Croatia generally and on EU tourism market. Firstly, Republic of Croatia should enhance its competitive position through the improvements in Human resources and labour market, and ICT Readiness. In the ICT readiness, Croatia needs to improve ICT use for biz-to-biz transactions, Internet use for biz-to-consumer 
ToSEE - Tourism in Southern and Eastern Europe, Vol. 5, pp. 581-595, 2019

A. Portolan: THE COMPETITIVENESS OF THE REPUBLIC OF CROATIA ON THE

transactions, and mobile-cellular telephone subscriptions. Regarding Human resources and labour market, improvement is needed in primary education enrollment rate, staff training, hiring and firing practices, easiness of finding skilled employees, and in easiness of hiring foreign labour. Secondly, the progress is also needed in Business environment because Croatia has a very bad business conditions for foreign investors, inefficient legal framework in settling disputes and challenging regulations, high taxation on incentives to work and to invest, high cost to deal with construction permits etc.

The main limitation of this paper is that research was based only on factors included in TTCI. The results would have been more accurate if used factors were complemented with, for example, Ritchie and Crouch's competitiveness model (2003) that investigates both, key stakeholders and tourists. In this research tourists' attitudes were not included, and it is known that destination could not be competitive if its visitors are dissatisfied.

Another limitation lies in the fact that research has covered only 28 EU countries. According Kayar and Kozak (2010) market share of EU members is declining. Thus, future studies should focus on developing tourism countries with a growing market share.

\section{REFERENCES}

Abreu Novais, M., Ruhanen, L. and Arcodia, C. (2018), "Destination competitiveness: A phenomenographic study", Tourism Management, Vol. 64, pp. 324-334, https://doi.org/10.1016/j.tourman.2017.08.014

Andrades, L. and Dimanche, F. (2017), "Destination competitiveness and tourism development in Russia: Issues and challenges", Tourism Management, Vol. 62, pp. 360-376, https://doi.org/10.1016/j.tourman.2017.05.008

Bălan, D., Balaure, V. and Vegheş, C. (2009), “Travel and Tourism Competitiveness of the World's Top Tourism Destinations: An Exploratory Assessment”, Annales Universitatis Apulensis Series Oeconomica, Vol. 11, No. 2, pp. 979-987.

Blanco-Cerradelo, L., Gueimonde-Canto, A., Fraiz-Brea, J.A. and Diéguez-Castrillón, M.I. (2018), "Dimensions of destination competitiveness: Analyses of protected area s in Spain", Journal of Cleaner Production, Vol. 177, pp. 782-794, https://doi.org/10.1016/j.jclepro.2017.12.242

Bošković, D., Težak Damijanić, A. and Saftić, D. (2010), "Analysis of the Istria tourism competitiveness The guests' perception", Tranzicija, Vol. 12, No. 25-26, pp. 162-169.

Chin-Tsai, L. and Ya-Ling, H. (2009), “Tourism Competitiveness Evaluation in Asian Countries Applying GRA and Sensitivity Analysis", Journal of Grey System, Vol. 3, pp. 269-278.

Dragoş Cîrstea, S. (2014), “Travel \& Tourism competitiveness: a study of world's top economic competitive countries", Procedia Economics and Finance, Vol. 15, pp. 1273-1280.

Craigwell, R. (2007), "Tourism Competitiveness in Small Island Developing States”, Research Paper No. 2007/19, United Nations University $i$ UNU-WIDER World Institute for Development Economics Research, Helsinki.

Croes, R. and Kubickova, M. (2013), "From potential to ability to compete: Towards a performance-based tourism competitiveness index", Journal of Destination Marketing \& Management, Vol. 2, Issue 3 , pp.146-154, https://doi.org/10.1016/j.jdmm.2013.07.002

Crouch, G.I., \& Ritchie, J.B. (1995), "Destination competitiveness and the role of the tourism enterprise", University of Calgary, Faculty of Management, pp. 43-48.

Crouch, G.I. and Ritchie, J.R.B. (1999), "Tourism, Competitiveness, and Societal Prosperity", Journal of Business Research, Vol. 44, pp. 137-152, https://doi.org/10.1016/S0148-2963(97)00196-3

Crouch, G.I., Ritchie, J.R.B. (2004),"'Application of the audit concept for destination diagnosis, Reinventing a tourism destination: Facing the challenge", in Weber, S. and Tomljenović, R. Competitiveness and branding, Institute for Tourism, Zagreb, pp. 7-25.

De Keyser, B. and Vanhove, N. (1994), "The competitive situation of tourism in the Caribbean area methodological approach", The Tourist Review, Vol. 49, Issue 3, pp. 19-22, https://doi.org/10.1108/eb058160 
ToSEE - Tourism in Southern and Eastern Europe, Vol. 5, pp. 581-595, 2019 A. Portolan: THE COMPETITIVENESS OF THE REPUBLIC OF CROATIA ON THE ...

Dragičević, V., Jovičić, D., Blešić, I., Stankov, U. and Bošković, D. (2012), "Business tourism destination competitiveness: A case ov Vojvodina province (Serbia)", Economic Research, Vol. 25, pp. 311 332, https://doi.org/10.1080/1331677X.2012.11517510

Dwyer, L. and Kim, C. (2003), "Destination Competitiveness: Determinants and Indicators", Current Issues in Tourism, Vol.6, Issue 5, pp. 369-414, https://doi.org/10.1080/13683500308667962

Dupeyras, A. and MacCallum, N. (2013), "Indicators for Measuring Competitiveness in Tourism: A Guidance Document”, OECD Tourism Papers, 2013/02, OECD Publishing, pp. 3-62, https://doi.org/10.1787/23071672

Gooroochurn, N. and Sugiyarto, G. (2005), "Competitiveness indicators in the travel and tourism industry", Tourism Economics, Vol. 11, No. 1, pp. 25-44, https://doi.org/10.5367\%2F0000000053297130

Gursoy D., Baloglu, S. and Chi, C. G. (2009), "Destination Competitiveness of Middle Eastern Countries: An Examination of Relative Positioning", An International Journal of Tourism and Hospitality Research, Vol 20, No. 1, pp. 151-163.

Hassan, S. (2000), "Determination of market competitiveness in an environmentally sustainable tourism industry", Journal of Travel Research, Vol. 38, Issue 3, pp. 239-245, https://doi.org/10.1177/004728750003800305

Heath, E. (2002), "Towards a model to enhance Africa's sustainable Tourism Competitiveness", Journal of Public Administration, Vol. 37, No. 3.1, pp. 327-353

Ivanov, S. and Webster, C. (2013), "Globalization as a driver of destination competitiveness", Annals of Tourism Research, Vol. 43, pp. 624-650.

Kayar, C.H. and Kozak, N. (2010), "Measuring destination competitiveness: An application of the Travel and Tourism Competitiveness Index (2007)", Journal of Hospitality Marketing and Management, Vol. 19, pp. 203-216, https://doi.org/10.1080/19368621003591319

Kunst, I. (2009), "Tourist Destination Competitiveness Assessment - Approach and Limitations", Acto Turistica, Vol. 21, No. 2, pp.129-159.

Ministry of tourism of Republic of Croatia (2018), Tourism in Numbers 2017.

National Competitiveness Council, viewed 10 February 2018, www.konkurentnost.hr

Petrović, J., Milićević, S. and Djeri, L. (2017), "The information and communication technology as a factor of destination competitiveness in transition countries in European Union", Tourism Economics, Vol. 23, Issue 6, pp. 1-9, https://doi.org/10.1177/1354816616653529

Pulido_Fernández, J.I., and Dodríguez-Díaz, B. (2016), "Reinterpreting the World Economic Forum's global competitiveness index", Tourism Management Perspectives, Vol. 20, pp. 131-140, https://doi.org/10.1016/j.tmp.2016.08.001

Rajh, E. and Piri Rajh S. (2001), "Poboljšanje interpretativnosti perceptualnih mapa transformacijom pravokutnih koordinata", Ekonomski Pregled, Vol. 52, No. 11-12, pp. 1368-1377.

Ritchie, J.R.B. and Crouch, G.I. (2003), The Competitive Destination, A Sustainable Tourism Perspective, CABI Publishing, Wallingford, UK.

World Tourism Organization UNWTO n.d. Tourism Highlights, 2018 Edition, viewed 10 February 2018 https://www.e-unwto.org/doi/pdf/10.18111/9789284419876

Ana Portolan, $\mathrm{PhD}$, Assistant Professor

University of Dubrovnik

Department of Economics and Business Economics

Lapadska obala 7, Dubrovnik, Croatia

Phone: +38520445923

E-mail: ana.portolan@unidu.hr 